\title{
Developing efficient transition metal-based water splitting catalyst using rechargeable battery materials
}

\author{
Hyunah Kim, Kisuk Kang ${ }^{\dagger}$ \\ Department of Materials Science and Engineering, Seoul National University \\ 배터리 소재를 이용한 전이금속 화합물 기반 물 분해 촉매 개발
}

\author{
김현아, 강기석 ${ }^{\dagger}$ \\ 서울대학교 재료공학부
}

(Received December 17, 2018; Accepted December 21, 2018)

\begin{abstract}
s
Water splitting is regarded as one of the most environmentally benign routes for hydrogen production. Nevertheless, the low energy efficiency to produce the hydrogen has been a critical bottleneck, which is attributable to the multielectron and multi-step reactions during water splitting reaction. In this respect, the development of efficient, durable, and inexpensive catalysts that can promote the reaction is indispensable. Extensive searching for new catalysts has been carried out for past decades, identifying several promising catalysts. Recently, researchers have found that conventional battery materials; particularly high-voltage intercalation-based cathode materials, could exhibit remarkable performance in catalyzing the water splitting process. One of the unique capabilities in this class of materials is that the valency state of metals and the atomic arrangement of the structure can be easily tailored, based on simple intercalation chemistry. Moreover, taking advantage of the rich prior knowledge on the intercalation compounds can offer the unexplored path to identify new water splitting catalysts.
\end{abstract}

Keywords: Water Spliting, Electrolysis, Rechargeable Battery, Catalyst, Oxygen Evolution Reaction

\section{1. 서론}

오늘날, 급속한 산업화와 기술의 발전으로 인하여 전세 계적으로 에너지 사용량이 급증했다. 현재 대부분의 에너
지는 석유나 석탄, 화석연료와 같은 탄소 기반의 자원으 로부터 얻어지고 있는데, 급증한 에너지 사용량만큼 환경 오염 및 기후온난화 문제가 심각해진 상황이다. 따라서, 에너지의 수요를 만족시키면서도 탄소기반 자원을 대체 
할 수 있는 친환경적인 새로운 대체 에너지원을 개발하는 것이 매우 중요하다. 이에 따라 태양에너지, 풍력에너지, 수소에너지 등과 같은 다양한 청정에너지원들에 대한 관 심이 급증했다. 이 중 수소에너지는 지구상에 풍부하게 존재하는 물로부터 얻을 수 있으며, $141.9 \mathrm{~kJ} / \mathrm{g}$ 정도로 상당히 높은 에너지밀도를 가지고 있다. 따라서, 수소에 너지는 현재의 에너지문제와 기후온난화를 동시에 해결 할 수 있는 가장 유망한 대체 에너지원으로 간주되고 있 다. ${ }^{1-6)}$

널리 사용되는 수소 생산 방법에는 크게 열화학적분해, 광분해 그리고 전기분해를 들 수 있다. 그 중 전기분해는 전기에너지를 이용해서 물을 분해해서 수소에너지를 얻 는 방법으로, 환경 오염의 원인이 되는 부산물들 없이 수 소와 산소만 생성되기 때문에 친환경적으로 수소에너지 를 생산할 수 있는 방법이다. 전기에너지로 물을 분해하 는 전체 반응식은 아래와 같이 표현될 수 있다.

$2 \mathrm{H}_{2} \mathrm{O}(\mathrm{l}) \rightarrow \mathrm{O}_{2}(\mathrm{~g})+2 \mathrm{H}_{2}(\mathrm{~g}) \quad \mathrm{E}=1.23 \mathrm{~V}$ (물 전기 분해 전체반응) $4 \mathrm{H}^{+}(\mathrm{aq})+4 \mathrm{e}^{-} \rightarrow 2 \mathrm{H}_{2}(\mathrm{~g}) \quad \mathrm{E}^{0}=0.00 \mathrm{~V}$ (수소발생반응, 환원전극) $2 \mathrm{H}_{2} \mathrm{O}(\mathrm{l}) \rightarrow \mathrm{O}_{2}(\mathrm{~g})+4 \mathrm{H}^{+}(\mathrm{ag})+4 \mathrm{e}^{-} \mathrm{E}^{0}=1.23 \mathrm{~V}$ (산소발생반응, 산화전극)

물 분해 전체 반응은 수소 발생 반응과 산소 발생 반응 의 두 반쪽 반응으로 이루어지며, 수소 발생 반응은 환원 전극, 산소 발생 반응은 산화 전극에서 각각 일어난다. (Fig. 1a) 물이 분해되기 위해서는 열역학적으로 $1.23 \mathrm{~V}$ 전압만큼의 에너지를 필요로 하지만, 실제로 반응이 진행
될 때에는 $1.23 \mathrm{~V}$ 의 전압을 인가하더라도 반응이 거의 일어나지 않는다. 이는 물 분해 반응이 다중 전자의 관여 로 일어나며 다중 단계 반응을 필요로 하기 때문에, 열역 학적인 요소뿐만 아니라 반응 속도 요소도 반응에 관여하 기 때문이다. 따라서, 물이 실제로 수소와 산소 분해되기 위해서는 열역학적으로 요구되는 전압 이상의 전압, 즉 과전압을 가해 주어야 한다. 과전압이 커질수록 더 많은 에너지를 가해 주어야 물이 분해 되기 때문에, 촉매를 이 용해서 각 전극 반응의 과전압을 줄여주는 것이 에너지 저장 효율을 높일 수 있는 방법이다. ${ }^{7-10)}$ 물 분해 반응의 두 반쪽 반응 중에서 산소 발생 반응은 일반적으로 아래 의 (1)-(4) 반응식과 같이 4가지 단계로 이루어진다고 알 려져 있다. ${ }^{11-13)}$ 우선, 활성 사이트(*)에 $\mathrm{OH}^{-}$가 와서 붙으 며 * $\mathrm{OH}$ 를 형성하고, 여기에서 $\mathrm{H}$ 가 떨어지며 활성사이 트에 $\mathrm{O}$ 가 흡착된 상태로 존재한다(*O). 그 다음, *O 에 또다른 $\mathrm{OH}^{-}$가 와서 붙으면서 $\mathrm{OOH}^{-}$를 형성한 후 $(* \mathrm{OOH}), \mathrm{O}_{2}$ 발생이 일어나며 다시 처음의 상태(*)로 돌 아오게 되면서 물이 분해되고 산소가 발생하는 반응이 일 어나는 것이다.

$$
\begin{aligned}
& *+\mathrm{H}_{2} \mathrm{O} \rightarrow * \mathrm{OH}+\mathrm{e}^{-}+\mathrm{H}^{+} \\
& * \mathrm{OH} \rightarrow * \mathrm{O}+\mathrm{e}^{-}+\mathrm{H}^{+} \\
& * \mathrm{O}+\mathrm{H}_{2} \mathrm{O} \rightarrow{ }^{*} \mathrm{OOH}+\mathrm{e}^{-}+\mathrm{H}^{+} \\
& * \mathrm{OOH} \rightarrow *+\mathrm{O}_{2}+\mathrm{e}^{-}+\mathrm{H}^{+}
\end{aligned}
$$

(*는 $\mathrm{OH}$ 및 $\mathrm{O}$ 가 흡착 할 수 있는 활성 사이트를 나타 낸다)
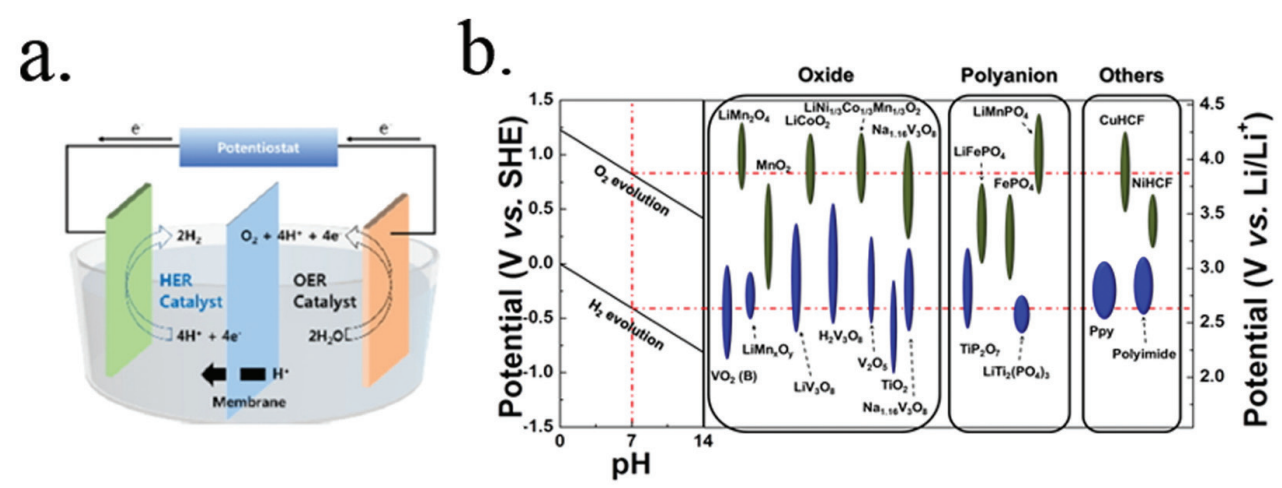

Fig. 1. 물의 전기 분해 반응에 대한 모식도. ${ }^{6)}$ 물 분해 반응에서의 이론적인 산소 및 수소 발생 전위와 배터리 소재의 산화 환원 전위. ${ }^{28)}$ 
따라서, 산소 발생 반응은 4 개 전자의 관여로 반응이 이루어지고, 산소 이중결합의 결합에너지가 높기 때문에 수소 발생 반응에 비해서 상대적으로 더 많은 과전압을 필요로 한다. ${ }^{6-8)}$ 그렇기 때문에 수소에너지의 경쟁력을 높이기 위해서는 고효율의 산소 발생 촉매 개발이 반드시 필요하다. 그동안 이리듐, 백금, 금과 같은 귀금속 계 물 질들은 우수한 촉매 특성으로 인해 산소 발생 반응 촉매 로 이용되어왔다. ${ }^{14-17)}$ 하지만 귀금속 물질 기반 촉매들은 비용적인 면에서 근본적인 한계를 지니게 된다. 따라서, 지구상에 널리 존재하는 저렴한 전이 금속을 이용하면서 도 높은 특성을 나타내는 촉매를 개발하기 위한 연구들이 활발하게 진행되고 있다.

\section{2. 본론}

\section{1 물 분해 촉매로 배터리 소재의 이용}

전이 금속 기반의 촉매들에 대한 연구가 진행되며 비정 질 $\mathrm{Co}$ 산화물로 이루어진 $\mathrm{Co}-\mathrm{Pi}$ 이나 $\mathrm{Ni}-\mathrm{Fe}$ 전이 금속 을 포함하는 층상 수산화물이 물 분해 특성이 좋은 새로 운 촉매 물질로 보고되었다. ${ }^{9,18,19)}$ 이와 같이 최적화 된 조 성 및 구조를 지니는 새로운 물질의 개발이 지속적으로 이루어지고 있지만, 최근에는 기존에 개발되어 있는 재료 들을 제어 및 조정하여 촉매의 효율을 향상시키는 방법이 주목받고있다. 기존 재료의 결정 구조, 전자 구조, 산화 상태 등을 조절하면 촉매의 효율을 향상시키는 동시에 촉 매의 특성에 직접적인 영향을 주는 인자들을 살펴볼 수 있고, 더 나아가서 촉매의 작동 메커니즘을 밝혀 낼 수 있 기 때문이다.

이와 같은 재료의 특성 조절을 위한 모델 시스템으로써 배터리 소재가 최근 광범위하게 연구되기 시작하였다. ${ }^{20-}$ 26) 특히, 배터리 소재 중, 양극 소재는 주로 전이 금속을 포함하고 있으며, 구동 할 때 전이금속의 산화가수 변화 가 지속적으로 일어난다는 점에서 물 분해 촉매와 공통점 이 있다. 또한 Fig. $1 \mathrm{~b}$ 에서 보여지듯이 배터리 소재의 산 화환원 전위와 물 분해 반응의 작동 전압이 유사하기 때 문에 촉매로써 사용될 수 있는 여지가 크다. ${ }^{28)}$ 양샤혼 그 룹과 타라스콘 그룹은 대표적인 배터리 소재인 $\mathrm{LiCoO}_{2}$ 와
$\mathrm{LiCoPO}_{4}$ 를 물 분해 산화 반응의 촉매로 사용하며 활성이 있다는 사실을 확인했다. ${ }^{29)}$ 하지만 여전히 귀금속 촉매에 비해 성능이 떨어지기 때문에 특성을 더욱 개선시킬 필요 가 있다. 촉매의 특성에 직접적인 영향을 주는 요소에는 촉매의 결정 구조, 전자 구조, 전이금속의 종류와 산화수 등이 있다. 배터리 소재의 두드러진 특징은 전이 금속의 산화수나 물질의 구조가 정교하게 조절될 수 있다는 점이 다. 배터리 소재는 리튬 이온이 삽입 되어있는 구조를 지 니고 있기 때문에 화학적 및 전기화학적인 방법으로 리튬 을 삽입시키거나 탈리시킨다면, 같은 구조 내에서 전이금 속의 산화수만 정교하게 조절할 수 있다. ${ }^{20-22)}$ 또한, 삽입 된 이온의 종류와 양을 조절함으로써 물질의 국부 구조에 왜곡을 가할 수도 있다. 이와 같은 배터리 소재를 이용한 연구는 촉매반응에서 각각의 요소들이 미치는 근본적인 영향을 밝히는데 중요한 단서를 제공할 뿐만 아니라, 더 나아가서 새로운 촉매를 디자인 할 수 있도록 만들어준 다. 또 다른 특징은, 배터리 소재는 수십년 간 연구가 진 행되어왔기 때문에 활용도가 높다는 점이다. 합성의 용이 성은 기존의 귀금속기반의 촉매에 비해서 저비용-대량 생산을 가능하게 만들어주며, 물 분해 촉매의 상업화를 위한 또 다른 돌파구가 될 수 있다. 대량 생산이 가능하고 이미 상용화 된 배터리 소재는 수소 에너지를 대량 생산 하는데 있어서 해결책이 될 수 있다. 따라서, 오랜시간동 안 개발되어 온 전이금속 기반의 배터리 소재를 모델 시 스템으로 이용하여 물 분해 촉매의 구동 원리를 근본적으 로 이해하고, 이를 바탕으로 효율적인 촉매를 디자인하여 친환경적으로 수소에너지를 얻으려는 연구들이 다양하 게 진행되고 있다.

\section{2 배터리 소재의 산화수 조절을 통한 효율적인 물 분해 촉매 개발}

물 분해 촉매는 전이 금속이 활성 사이트로 작용하며 산화수 변화를 통해 물 분해 반응을 촉진시키기 때문에 전이금속의 산화수에 대한 연구가 집중적으로 이루어지 고 있다. 하지만, 여러 물질 군을 촉매로 이용하는 경우, 결정 구조와 전이금속의 종류, 전이금속의 산화수 등 촉 매의 여러 요소가 동시에 변하기 때문에 전이금속 산화수 
a.

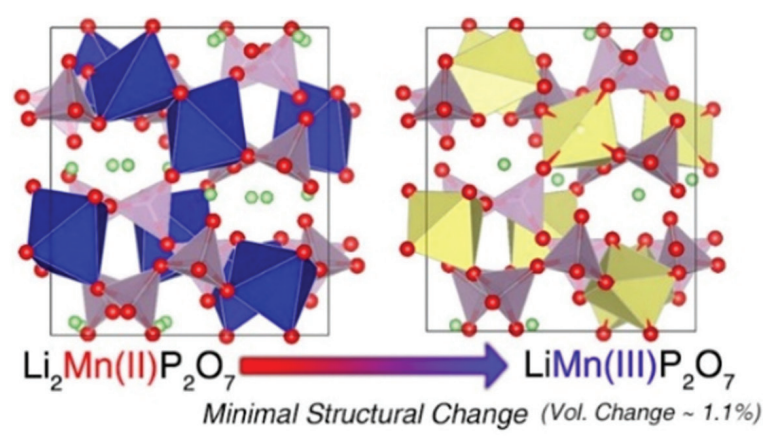

b.

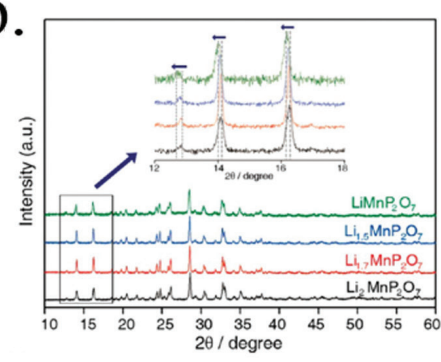

c.

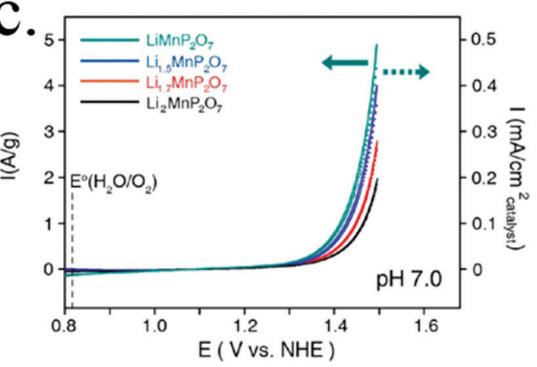

Fig. 2. $\mathrm{Li}_{2-x} \mathrm{MnP}_{2} \mathrm{O}_{7(0<x(1)}$ 촉매들의 $\mathrm{X}$ 선 회절 분석 패턴 및 물 분해 특성. ${ }^{20)}$

의 영향만을 구분해서 밝혀내기 어려웠다. 따라서 연구진 들은 배터리 재료를 물 분해 촉매로 이용해서 촉매 특성 에 영향을 주는 각 요소들을 분리하여 관찰하였다.

배터리 재료의 큰 특징은 전이 금속의 산화수와 결정 구조를 각각 독립적으로 쉽게 제어 할 수 있다는 점이다. 같은 물질 내에서 화학적 및 전기 화학적인 방법으로 리 튬을 빼 준다면, 최소한의 결정 구조 변화 내에서 리튬 원 자의 양을 정확하게 조절할 수 있다. 최근, 국내 연구진 은 이 방법을 통해 물 분해 촉매 반응에서 전이금속 산화 수의 영향력을 결정구조와 분리하여 밝혀냈다. ${ }^{20)}$ 리튬 이 온 배터리 양극 소재인 $\mathrm{Li}_{2} \mathrm{MnP}_{2} \mathrm{O}_{7}$ 을 모델 시스템으로 선 택한 후, 강력한 산화제인 $\mathrm{NO}_{2} \mathrm{BF}_{4}$ 를 이용해 화학적인 방법으로 delithiation 시켜서 $\mathrm{Li}_{2-x} \mathrm{MnP}_{2} \mathrm{O}_{7(0<x<1)}$ 을 합성 했다. $\mathrm{Li}_{2-\mathrm{x}} \mathrm{MnP}_{2} \mathrm{O}_{7(0<\mathrm{x}<1)}$ 에서 포함하고 있는 리튬 이온의 개수가 2 개에서 1 개로 변할수록 $\mathrm{Mn}$ 의 산화수는 2 에서 3 으로 점진적으로 증가하였으며, XRD 분석을 통해 결정 구조를 분석한 결과 최대한으로 delithiation 시킨 $\mathrm{LiMnP}_{2} \mathrm{O}_{7}$ 물질의 경우에서도 원래의 구조에 비하여 부 피 변화가 $1 \%$ 이내로 최소한으로 이루어 진 것을 확인하
였다. (Fig. $2 \mathrm{a}, \mathrm{b}) \mathrm{Li}_{2-x} \mathrm{MnP}_{2} \mathrm{O}_{7(0<x<1)}$ 의 물 분해 특성을 비교하자, Fig. $2 \mathrm{c}$ 와 같이 $\mathrm{Mn}$ 의 산화수가 2에서 3으로 증가함에 따라 $\mathrm{Li}_{2} \mathrm{MnP}_{2} \mathrm{O}_{7}<\mathrm{Li}_{1.7} \mathrm{MnP}_{2} \mathrm{O}_{7}<\mathrm{Li}_{1.5} \mathrm{MnP}_{2} \mathrm{O}_{7}$ $<\mathrm{LiMnP}_{2} \mathrm{O}_{7}$ 의 순으로 촉매 성능이 향상되는 것을 관찰 했다. 이 연구는 $\mathrm{Mn}$ 의 산화 상태가 산소 발생 반응에 미 치는 영향에 대한 이해도를 높였다.

이취 그룹에서는 리튬 이온 배터리의 양극 재료로써 가 장 보편적으로 사용되는 $\mathrm{LiCoO}_{2}$ 를 전기화학적인 방법으 로 delithiation 시켜서 코발트의 산화수를 조절했다. (Fig. $3 \mathrm{a})^{21)} \mathrm{LiCoO}_{2}$ 를 Fig. $3 \mathrm{~b}$ 와 같이 높은 전위로 충전 하여 delithiated $\mathrm{LiCoO}_{2}\left(\mathrm{De}-\mathrm{LiCoO}_{2}\right)$ 상을 얻은 후, 두 물질의 물 분해 촉매 특성을 비교하였다. Fig. $3 \mathrm{c}$ 에서 보 여지듯이 $\mathrm{De}-\mathrm{LiCoO}_{2}$ 가 $1.6 \mathrm{~V}$ 에서 약 $3.8 \mathrm{~mA} \mathrm{~cm}$-2 의 값을 보이며 $\mathrm{LiCoO}_{2}$ 에 비해 크게 향상된 특성을 보인다 는 것을 발견했다. $\mathrm{LiCoO}_{2}$ 와 $\mathrm{De}-\mathrm{LiCoO}_{2}$ 의 물 분해 특 성이 다르게 나타나는 이유는, $\mathrm{De}-\mathrm{LiCoO}_{2}$ 에서 활성사 이트인 $\mathrm{Co}$ 가 더 높은 산화수로 존재하는데 이것이 촉매 반응에 도움을 주었기 때문이라고 추측하고 있다. 산소 발생 반응 중에서 * $\mathrm{O}$ 에 $\mathrm{OH}^{-}$가 붙어서 ${ }^{*} \mathrm{OOH}^{-}$이 형성 
a.
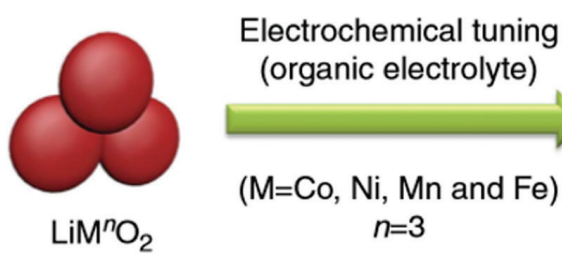

$(\mathrm{M}=\mathrm{Co}, \mathrm{Ni}, \mathrm{Mn}$ and $\mathrm{Fe})$ $n=3$

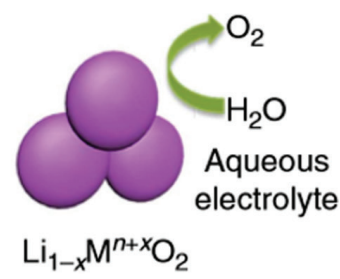

b.

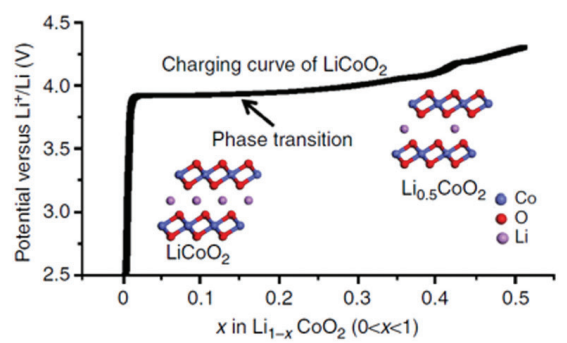

d.

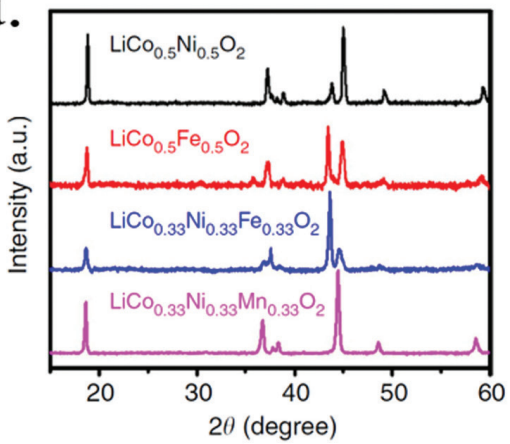

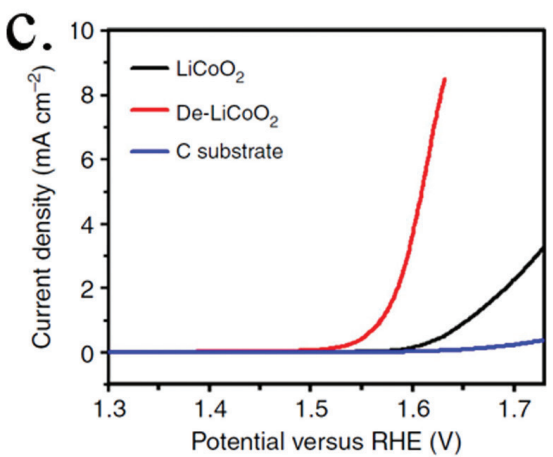

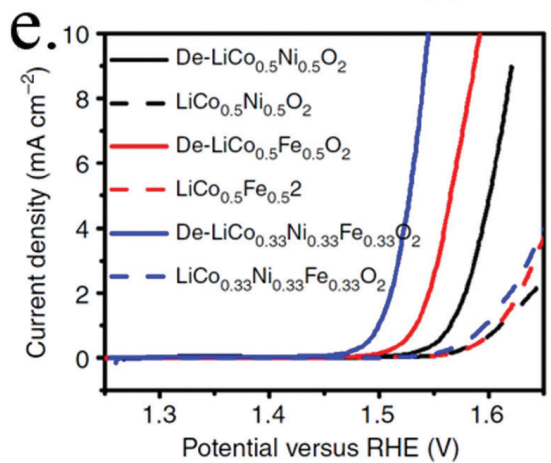

Fig. 3. $\mathrm{LiCOO}_{2}$ delithiation 에 따른 전이 금속의 산화수 조절 전략도 및 물 분해 촉매 특성. ${ }^{21}$

되는 3 번째 단계가 속도 결정 단계로 보편적으로 간주되 고 있다. 이취 그룹에서는 $\mathrm{De}-\mathrm{LiCoO}_{2}$ 에서 $\mathrm{Co}$ 의 상대적 으로 높은 산화수는 $\mathrm{Co}$ 의 친 전자 성을 높여주었고, 따라 서 속도 결정 단계에서의 $\mathrm{OH}^{-}$의 흡착을 용이하게 해주었 으며, 결과적으로 물 분해 활성을 증가시켰다고 추측한 다. 이들은 전기 화학적 delithiation을 통한 전이금속의 산화수 변화가 물 분해 특성에 긍정적인 효과를 나타낸다 는 결과를 보편화시키기 위해 $\mathrm{LiCoO}_{2}$ 이외에 여러 가지 혼합 금속 산화물에도 적용해 보았다. Fig. $3 \mathrm{~d}$ 에서 보여 지듯이 $\mathrm{LiCo}_{0.5} \mathrm{Ni}_{0.5} \mathrm{O}_{2}, \mathrm{LiCo}_{0.5} \mathrm{Fe}_{0.5} \mathrm{O}_{2}, \mathrm{LiCo}_{0.33} \mathrm{Ni}_{0.33} \mathrm{Fe}_{0.33}$ $\mathrm{O}_{2}$ 및 $\mathrm{LiCo}_{0.33} \mathrm{Ni}_{0.33} \mathrm{Mn}_{0.33} \mathrm{O}_{2}$ 을 합성한 후, 각 물질을 전 기화학적인 방법으로 delithiation 시켰다. 그 후 물 분해
특성을 비교해본 결과, Fig. $3 \mathrm{e}$ 와 같이 delithiation 된 물질들의 촉매 특성이 모두 증가한 것을 알 수 있었다.

비슷한 시도로, $\mathrm{LiCoO}_{2}$ 와 같은 옥사이드 기반의 물질 외에도, 인산염을 이용한 $\mathrm{LiMPO}_{4}$ 또한 물 분해 촉매로 응용되었다. 이취 그룹은 배터리의 양극 소재로 사용되는 $\mathrm{LiMPO}_{4}(\mathrm{M}=\mathrm{Co}, \mathrm{Ni}, \mathrm{Fe})$ 의 올리빈 물질군에서도 리튬의 양을 조절하면서 물 분해 촉매 효과를 관찰했다. Fig. $4 \mathrm{a})^{22)}$ 그 결과, $\mathrm{LiCoO}_{2}$ 에서와 같이 배터리의 충전 반응 을 통해 전기화학적으로 delithiation 시킨 $\mathrm{LiMPO}_{4}$ 에서 향상된 물 분해 촉매 특성이 나타났다. 촉매 특성을 더 증 가시키기 위해 연구진은 $\mathrm{LiMPO}_{4}$ 를 전기전도도가 높은 그래핀 산화물 $(\mathrm{rGO})$ 에 고정시켰다. $\mathrm{LiMPO}_{4}$ 물질은 
a.

b.
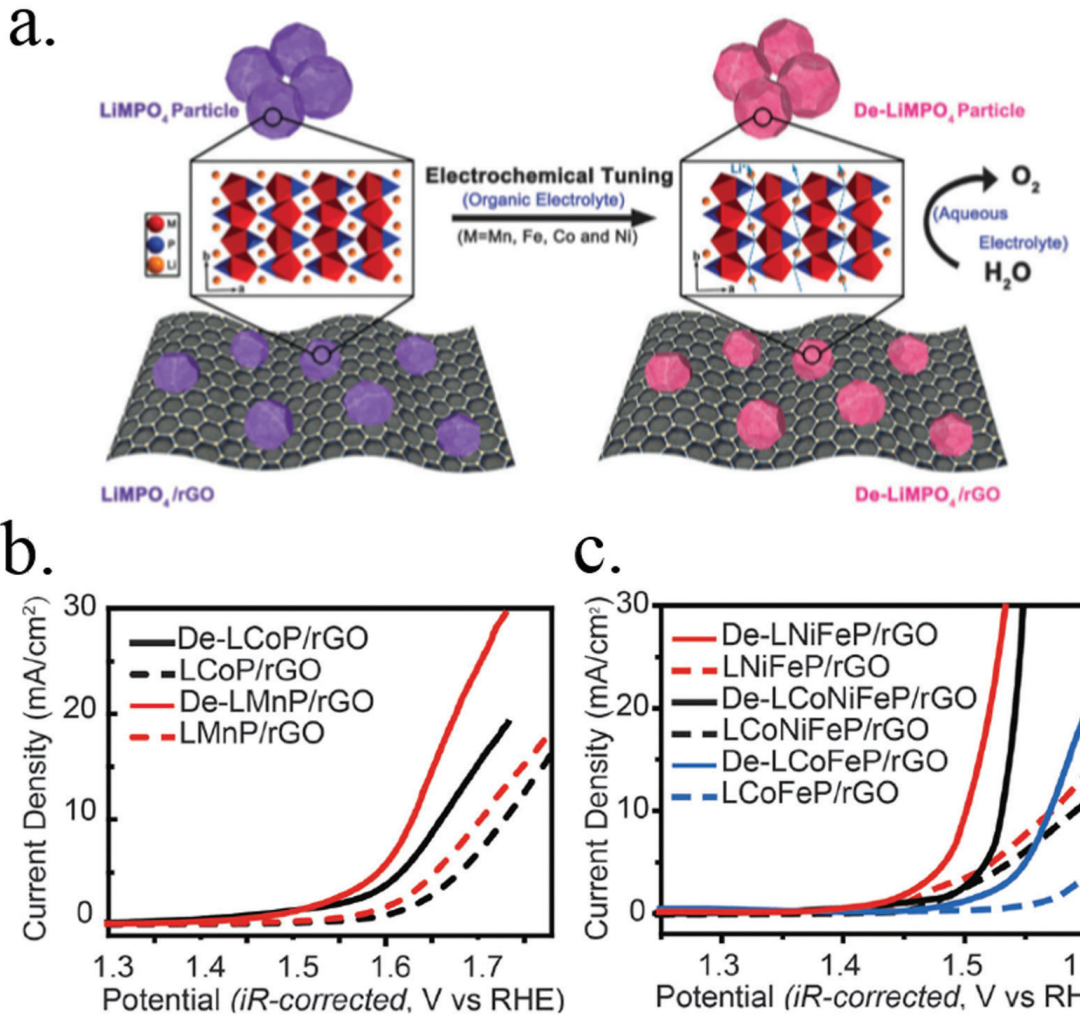

c.

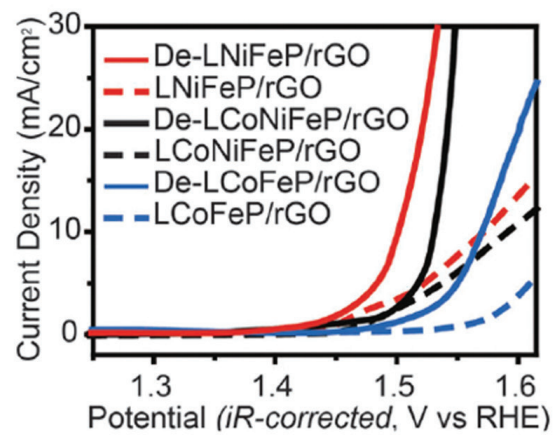

Fig. 4. $\mathrm{LiMPO}_{4}$ delithiation 에 따른 전이 금속의 산화수 조절 전략도 및 물 분해 촉매 특성. ${ }^{22)}$

$\mathrm{PO}_{4}{ }^{3-}$ 가 강력한 공유결합을 형성하고 있기 때문에 낮은 전자전도도 및 이온전도도를 가진다고 알려져 있다. 그래 핀 산화물은 넓은 표면적과 높은 전기전도도를 가지고 있 기 때문에 전자 전달 촉진을 통해서 촉매 반응에 시너지 효과를 줄 수 있을 것이라 기대했고, 실제로 Fig. $4 \mathrm{~b}$ 와 $4 \mathrm{c}$ 에서 보여지듯 촉매 특성이 증가한 것을 관찰했다. 이 중 delithiation 시킨 $\mathrm{Li}(\mathrm{NiFe}) \mathrm{PO}_{4} / \mathrm{rGO}$ 는 알칼리 분위 기 하에서 $270 \mathrm{mV}$ 의 낮은 과전압으로 $10 \mathrm{~mA} \mathrm{~cm}$ 의 전류 밀도를 생성하며 귀금속 촉매와 견줄 수 있을 만한 촉매 특성을 보였다.

\section{3 배터리 소재의 다중 금속 이용을 통한 효율적인 물 분해 촉매 개발}

배터리 소재를 이용해서 촉매의 산화수를 조절하는 방 법 외에도, 촉매에 다중 전이금속을 이용해서 효율적인 촉매를 개발하는 방법이 보고되었다. 도핑은 산화물에서
전이 금속의 전자 구조를 조절하기 위한 효과적인 방법으 로 다양한 응용 분야에서 적용되어왔다. ${ }^{27,30,31)}$ 전이 금속 은 물 분해 반응에서의 활성 사이트로 작용하기 때문에, 단일 금속이 아닌 다중 금속의 사용은 촉매의 반응에 직 접적으로 영향을 주며 현저한 성능 변화를 가져 올 수 있 다. ${ }^{23-25)}$ 실제로, 샤오종핑 그룹에서는 $\mathrm{Fe}$ 를 $\mathrm{LiCoO}_{2}$ 에 도 핑할 때, 물 분해 촉매 특성이 향상되는 것을 관찰했다. ${ }^{24)}$ $10 \mathrm{~mA} \mathrm{~cm}$ 의 전류 밀도 값을 기준으로, $\mathrm{LiCo}_{0.8} \mathrm{Fe}_{0.2} \mathrm{O}_{2}$ 는 $340 \mathrm{mV}$ 의 과전압을 나타내며 단일 전이금속으로 이 루어진 $\mathrm{LiCoO}_{2}$ 가 $430 \mathrm{mV}$ 의 과전압을 나타내는 것과 비 교하여 상당히 향상된 촉매 특성을 보였다. (Fig. 5a) $\mathrm{LiCo}_{0.8} \mathrm{Fe}_{0.2} \mathrm{O}_{2}$ 뿐만 아니라, $\mathrm{Fe}$ 가 도핑된 $\mathrm{LiCo}_{1-\mathrm{x}} \mathrm{Fe}_{\mathrm{x}} \mathrm{O}_{2}$ $(0.1 \leq \mathrm{x} \leq 0.8)$ 물질들 모두 도핑되지 않은 $\mathrm{LiCoO}_{2}$ 및 $\mathrm{LiFeO}_{2}$ 보다 높은 물 분해 특성을 나타내며, 이는 $\mathrm{Fe}$ 와 $\mathrm{Co}$ 사이에 시너지 효과가 존재함을 암시한다. XPS 분석 결과, Fig. $5 b$ 에서 보여지듯이 $\mathrm{LiCoO}_{2}$ 에 비해서 $\mathrm{LiCO}_{0.8}$ 


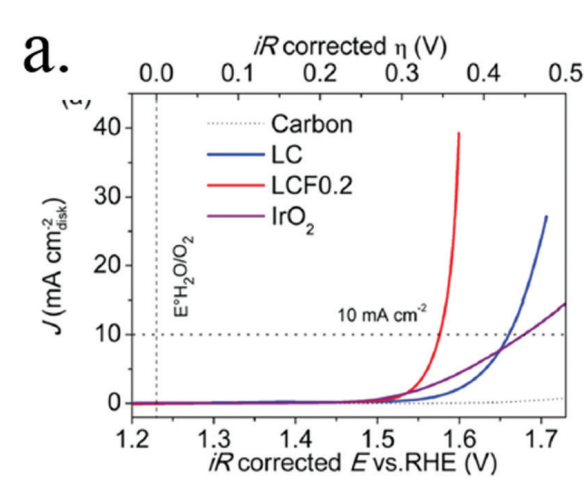

b.
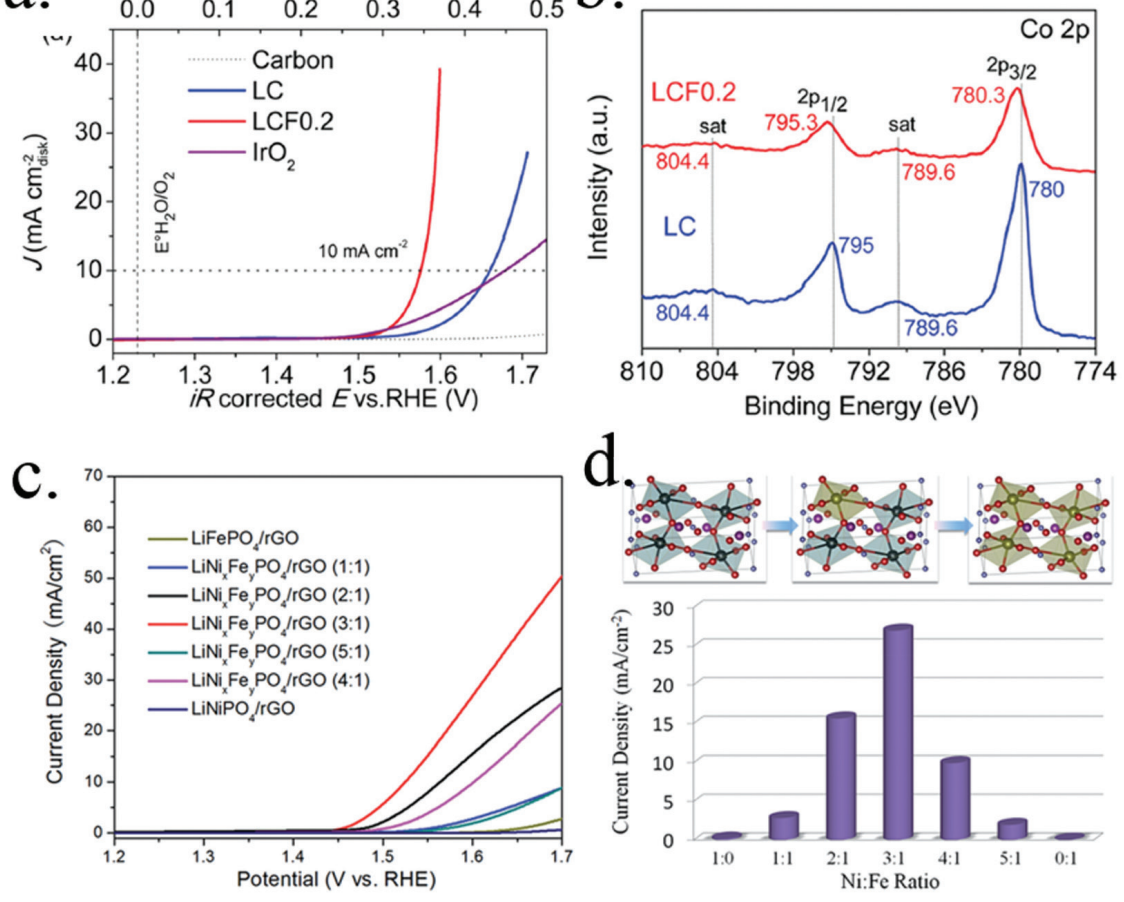

Fig. 5. $\mathrm{LiCO}_{1-x} \mathrm{Fe}_{x} \mathrm{O}_{2}^{24)}$ 및 $\mathrm{LiNi}_{x} \mathrm{Fe}_{y} \mathrm{PO}_{4}{ }^{25}$ 와 같이 다중전이금속을 이용한 물 분해 특성 조절.

$\mathrm{Fe}_{0.2} \mathrm{O}_{2}$ 의 $\mathrm{Co}$ 가 더 높은 산화수 상태로 존재하고 있음을 밝혀냈다. 연구진은 $\mathrm{LiCo}_{0,8} \mathrm{Fe}_{0,2} \mathrm{O}_{2}$ 에서 $\mathrm{Fe}$ 도핑으로 인 해 표면의 Co 3 가가 부분적으로 4 가 상태로 존재하게 되 면서 친 전자 성이 강해졌고, 이와 같은 현상은 $\mathrm{OH}^{-}$가 *O에 흡착되면서 * $\mathrm{OOH}^{-}$를 형성하는 속도 결정 단계(산 소 발생 반응 3 번째 단계)를 용이하게 만들어주기 때문에 전체적인 물 분해 활성이 증가했다고 보고했다. 이취 그 룹에서도 $\mathrm{LiCoO}_{2}$ 에 비해서 $\mathrm{LiCo}_{0.5} \mathrm{Ni}_{0.5} \mathrm{O}_{2}, \mathrm{LiCo}_{0.5} \mathrm{Fe}_{0.5}$ $\mathrm{O}_{2}, \mathrm{LiCo}_{0.33} \mathrm{Ni}_{0.33} \mathrm{Fe}_{0.33} \mathrm{O}_{2}$ 및 $\mathrm{LiCo}_{0.33} \mathrm{Ni}_{0.33} \mathrm{Mn}_{0.33} \mathrm{O}_{2}$ 와 같 은 다중 금속 산화물에서 더 향상된 물 분해 특성이 나타 난다는 것을 관찰했다. ${ }^{21}$

젠동밍 그룹에서는 올리빈 구조의 배터리 소재를 이용 해서 $\mathrm{Ni}$ 와 $\mathrm{Fe}$ 를 비율별로 혼합하며 물 분해 촉매 특성을 보고했다. ${ }^{25)}$ 촉매 반응에서의 다중 전이금속의 영향을 살 펴보기 위해 $\mathrm{LiNiPO}_{4}$ 와 $\mathrm{LiFePO}_{4}$ 물질을 기반으로 $\mathrm{LiNi}_{\mathrm{x}} \mathrm{Fe}_{\mathrm{y}} \mathrm{PO}_{4}$ 에서 $\mathrm{Ni}$ 와 $\mathrm{Fe}$ 비율을 $1: 1,2: 1,3: 1,4$ $: 1$ 그리고 $5: 1$ 로 변화시켰으며, 전기전도도를 높이기
위해 모든 물질은 그래핀 산화물 $(\mathrm{rGO})$ 에 고정시켰다. 그 리고 물 분해 특성을 비교한 결과, $\mathrm{Ni}$ 와 $\mathrm{Fe}$ 가 혼합되어 존재하는 물질들은 도핑되지 않은 $\mathrm{LiNiPO}_{4}$ 와 $\mathrm{LiFePO}_{4}$ 보다 모두 높은 촉매 특성을 보인다는 것을 확인했다. 그 중에서도 특히 $\mathrm{LiNi}_{0.75} \mathrm{Fe}_{0.25} \mathrm{PO}_{4}$ 가 알칼리성 전해질 조건 에서 $295 \mathrm{mV}$ 의 과전압으로 $10 \mathrm{~mA} \mathrm{~cm}$-2의 전류 밀도에 도달하며 가장 높은 효율을 나타냈다. (Fig. $5 \mathrm{c}, \mathrm{d}$ ) 이러한 결과는 $\mathrm{Ni}$ 와 $\mathrm{Fe}$ 가 $\mathrm{LiNi}_{\mathrm{x}} \mathrm{Fe}_{\mathrm{y}} \mathrm{PO}_{4}$ 내에서 단순한 혼합물로 작용하지 않으며, $\mathrm{Ni}$ 와 $\mathrm{Fe}$ 사이에 상호 작용이 산소 발생 반응 속도의 향상을 가져온다는 것을 뜻한다.

\section{4 배터리 소재의 국부 구조 조절을 통한 효율적인 물 분해 촉매 개발}

또 다른 방법으로, 촉매의 국부 구조 조절을 통해 효율 적인 촉매를 개발하는 방법이 보고되었다. 표면 원자들 사이의 거리가 촉매 특성에 영향을 준다는 사실은 널리 알려져 있다. 백금의 경우, $1 \%$ 의 격자 변형만으로도 백 
a.

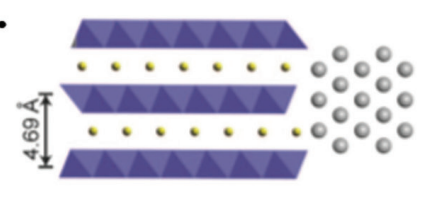

LCO

Pt (pristine)
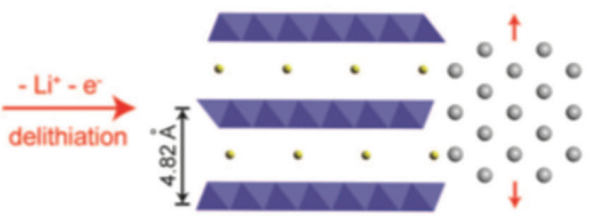

$\mathrm{L}_{0.5} \mathrm{CO}$

Pt (tension)

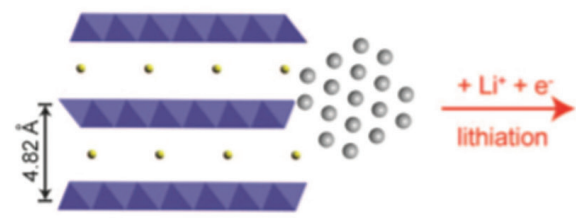

$\mathrm{L}_{0.5} \mathrm{CO} \quad \mathrm{Pt}$ (pristine)

Co-O octahedra

b.
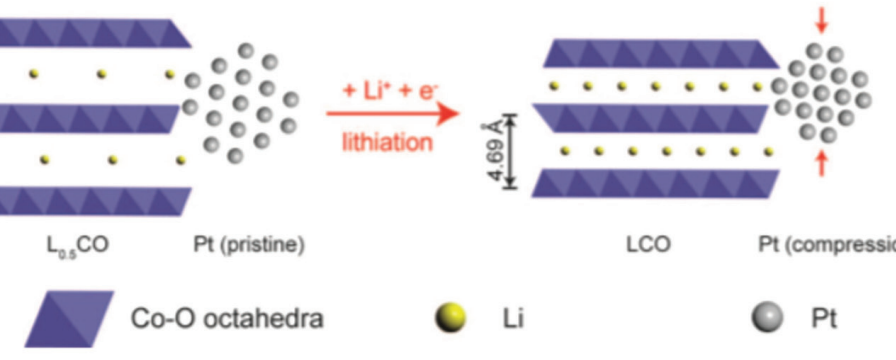

LCO

Pt (compression)

Li

- $\mathrm{Pt}$
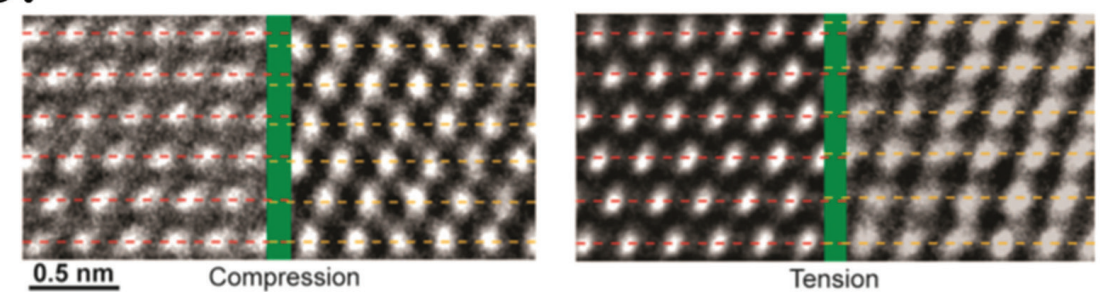

c.
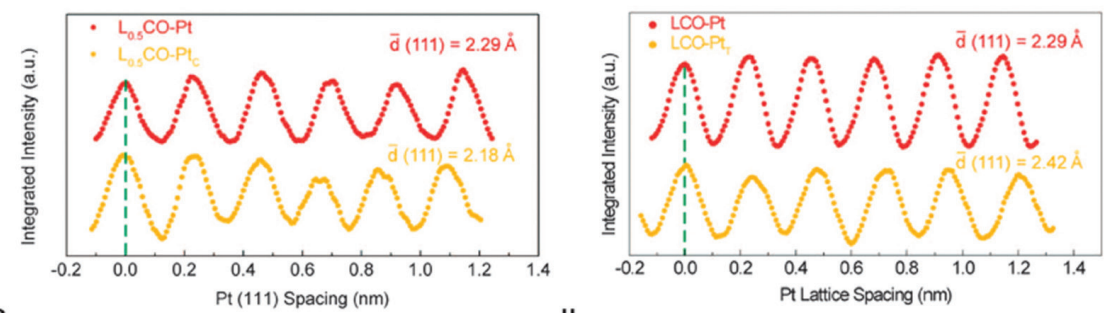

Fig. 6. $\mathrm{LiCOO}_{2}$ 를 이용해서 백금 촉매에 압축 및 인장 변형을 가해주는 방법. ${ }^{26)}$

금 전자 구조가 $\sim 0.1 \mathrm{eV}$ 까지 변할 수 있으며, 이는 물 분해 반응에서 활성사이트와 중간생성물들과의 결합 세 기를 강화시키거나 약화시킬 수 있다고 한다. ${ }^{32,33)}$ 따라서 촉매에 압축 또는 인장 변형을 가해 주며 국부 구조를 조 절하는 연구들이 진행되었다. 노스코브 그룹과 이취 그룹 은 대표적인 배터리 소재인 $\mathrm{LiCoO}_{2}$ 를 사용하여 백금 촉 매의 격자를 직접적으로 제어하고 촉매 특성을 조절하는 방법을 보고했다. ${ }^{26)}$ 배터리 소재에서 $\mathrm{Li}$ 이온을 전기화학
적으로 삽입 또는 제거하는 경우 부피와 격자 간격을 수 퍼센트에서 수 배로 변화시킬 수 있다. 예를 들어, $\mathrm{LiCoO}_{2}$ 는 충전 및 방전 동안 약 $3 \%$ 부피 변화가 일어 난다고 한다. 따라서, $\mathrm{LiCoO}_{2}$ 를 지지체로 사용하여 부피 변화를 정확하게 제어하고, 지지 된 촉매에 압축 변형 또 는 인장 변형을 유도하기 위해 $\mathrm{LiCoO}_{2}$ 의 표면에 작은 Pt 나노 입자 $(\mathrm{NPS} \sim 5 \mathrm{~nm})$ 를 증착 시켰다. $\mathrm{LiCoO}_{2}$ 를 이용 해서 백금 촉매에 압축 및 인장 변형을 가해주고 제어하 
기 위한 전략은 Fig. $6 \mathrm{a}$ 에 나타나 있다. $\mathrm{Pt}$ 를 $\mathrm{LiCoO}_{2}$ 위 에 증착한 후 배터리의 충전 반응을 통해 $\mathrm{Li}$ 이온을 빼면 인장 변형이 가해지고 반대로 $\mathrm{Pt}$ 를 $\mathrm{Li}_{0.5} \mathrm{CoO}_{2}$ 위에 증착 한 후 배터리의 충전 반응을 통해 $\mathrm{Li}$ 이온이 삽입하면 압 축 변형이 가해진다. 실제로 고분해능 TEAM을 이용해서 기판에 의해 유도 된 Pt (111) 면에서 약 $5 \%$ 정도의 격자 압축 및 인장 변형이 일어난 것을 직접적으로 관찰했다. (Fig. 6b) Fig. 6c 에서는 압축 및 인장된 Pt (111) 격자의 픽셀 강도를 적분한 값을 보여주고 있다. 초기 Pt (111) 간 격은 평균적으로 $2.29 \AA$ 이며, 압축된 $\mathrm{Pt}$ 는 $2.18 \AA$ 그리고 인장된 Pt는 $2.42 \AA$ 평균 격자 거리를 가지고 있음을 뜻 한다. 이와 같은 촉매의 국부 구조 변형은 산소 환원 반응 의 촉매 특성에 $90 \%$ 향상 또는 $40 \%$ 억제를 유도한다는 사실을 관찰했다.

\section{3. 요약}

물을 산소와 수소로 분해해서 수소에너지를 얻는 방법 은 친환경적으로 고효율의 에너지를 얻을 수 있기 때문에 각광받고 있지만, 근본적인 한계로 여겨지는 과전압을 줄 이고 에너지 변환 효율을 높여주기 위해서는 저렴하면서 도 높은 특성을 보이는 촉매의 개발이 필수적이다. 높은 특성을 보이는 새로운 촉매 물질에 대한 연구도 지속적으 로 진행되고 있지만, 최근에는 촉매 효율을 결정하는 인 자들에 대한 이해를 바탕으로 알려진 촉매의 특성을 체계 적으로 개선하기 위한 연구들이 주목받고 있다. 그 모델 시스템으로 전이금속 화합물 기반의 배터리 소재들이 물 분해 촉매로 이용되었다. 배터리 소재는 전이금속의 산 화-환원 전압이 물 분해 반응이 일어나는 전압과 비슷하 며, 산화수, 국부 구조 및 전이금속 도핑을 각각의 변수 로써 제어하고 조절하기 쉽다. 따라서, 각각의 변수와 촉 매 특성의 연관성을 이해할 수 있고, 이를 기반으로 새로 운 고효율의 촉매를 개발 할 수 있다는 장점이 있다. 따라 서 에너지 저장 물질로만 인정되었던 배터리 소재를 이용 해서 촉매의 활성에 영향을 주는 산화수, 국부 구조, 전 이금속의 종류 등과 같은 요소들을 제어하고 조절하는 연 구들이 다양하게 진행되었고, 이를 바탕으로 새로운 촉매
를 설계하는데 중요한 지침을 얻을 수 있었다. 산소 발생 반응의 과전압이 물 분해 반응에서의 주된 문제점으로 여 겨지는 만큼, 효율적인 촉매의 개발이 전체 물 분해 효율 의 향상에 커다란 기여를 할 것이고 이를 통하여 친환경 적으로 수소에너지를 얻을 수 있을 것으로 기대한다.

\section{참고문헌}

1. M. G. Lee, J. S. Park, H. W. Jang, "SolutionProcessed Metal Oxide Thin Film Nanostructures for Water Splitting Photoelectrodes: A Review." J. Korean Ceram. Soc., 55, 185-202 (2018).

2. M. Jacobson, W. Colella, D. Golden, "Cleaning the air and improving health with hydrogen fuel-cell vehicles." Science, 308, 1901-1905 (2005).

3. S. Chu, Y. Cui, N. Liu, "The path towards sustainable energy." Nat. Mater., 16, 16 (2017).

4. M. Grätzel, "Photoelectrochemical cells." Nature 414, 338 (2001).

5. N. S. Lewis, D. G. Nocera, "Powering the planet: Chemical challenges in solar energy utilization." Proc. Natl. Acad. Sci. U. S. A., 103, 15729-15735 (2006).

6. H. Seo, K. H. Cho, H. Ha, S. Park, J. S. Hong, K. Jin, K. T. Nam, "Water oxidation mechanism for 3d transition metal oxide catalysts under neutral condition." J. Korean Ceram. Soc., 54, 1-8 (2017).

7. J. K. Hurst, "In pursuit of water oxidation catalysts for solar fuel production." Science, 328, 315-316 (2010).

8. T. A. Betley, Q. Wu, T. Van Voorhis, D. G. Nocera, Electronic design criteria for $\mathrm{O}-\mathrm{O}$ bond formation via metal- oxo complexes." Inorg. Chem., 47, 1849-1861 (2008).

9. M. W. Kanan, D. G. Nocera, "In situ formation of an oxygen-evolving catalyst in neutral water containing phosphate and $\mathrm{CO}^{2+}$." Science, 321, 1072-1075 (2008).

10. J. Suntivich, K. J. May, H. A. Gasteiger, J. B. Goodenough, Y. Shao-Horn, "A perovskite oxide optimized for oxygen evolution catalysis from molecular orbital principles." Science, 334, 1383-1385 (2011).

11. H. -Y. Su, Y. Gorlin, I. C. Man, F. Calle-Vallejo, J. K. Nørskov, T. F. Jaramillo, J. Rossmeisl, "Identifying active surface phases for metal oxide electrocatalysts: a study of manganese oxide bi-functional catalysts for oxygen reduction and water oxidation catalysis." 
Phys. Chem. Chem. Phys., 14, 14010-14022 (2012).

12. M. Bajdich, M. García-Mota, A. Vojvodic, J. K. $\mathrm{N} ø$ rskov, A. T. Bell, "Theoretical investigation of the activity of cobalt oxides for the electrochemical oxidation of water." J. Am. Chem. Soc., 135, 1352113530 (2013).

13. H. Kim, J. Park, I. Park, K. Jin, S. E. Jerng, S. H. Kim, K. T. Nam, K. Kang, "Coordination tuning of cobalt phosphates towards efficient water oxidation catalyst." Nat. Commun., 6, 8253 (2015).

14. Y. Lee, J. Suntivich, K. J. May, E. E. Perry, Y. ShaoHorn, "Synthesis and activities of rutile $\mathrm{IrO}_{2}$ and $\mathrm{RuO}_{2}$ nanoparticles for oxygen evolution in acid and alkaline solutions." J. Phys. Chem. Lett., 3, 399-404 (2012).

15. L. Tong, L. Duan, Y. Xu, T. Privalov, L. Sun, "Structural modifications of mononuclear ruthenium complexes: a combined experimental and theoretical study on the kinetics of ruthenium-catalyzed water oxidation.” Angew. Chem.,Int. Ed., 50, 445-449 (2011).

16. L. Duan, F. Bozoglian, S. Mandal, B. Stewart, T. Privalov, A. Llobet, L. Sun, A molecular ruthenium catalyst with water-oxidation activity comparable to that of photosystem II." Nat. Chem., 4, 418 (2012).

17. K. S. Joya, N. K. Subbaiyan, F. D’Souza, H. J. de Groot, "Surface-immobilized single-site iridium complexes for electrocatalytic water splitting." Angew. Chem.,Int. Ed., 51, 9601-9605 (2012).

18. F. Dionigi, P. Strasser, NiFe-Based (Oxy) hydroxide Catalysts for Oxygen Evolution Reaction in NonAcidic Electrolytes." Adv. Energy Mater., 6, 1600621 (2016).

19. R. Subbaraman, D. Tripkovic, K.-C. Chang, D. Strmcnik, A. P. Paulikas, P. Hirunsit, M. Chan, J. Greeley, V. Stamenkovic, N. M. Markovic, "Trends in activity for the water electrolyser reactions on $3 \mathrm{~d} M$ (Ni, Co, Fe, Mn) hydr (oxy) oxide catalysts." Nat. Mater., 11, 550 (2012).

20. J. Park, H. Kim, K. Jin, B. J. Lee, Y.-S. Park, H. Kim, I. Park, K. D. Yang, H.-Y. Jeong, J. Kim, K. T. Hong, H. W. Jang, K. Kang, K. T. Nam, "A new water oxidation catalyst: lithium manganese pyrophosphate with tunable $\mathrm{Mn}$ valency." J. Am. Chem. Soc., 136, 4201-4211 (2014).

21. Z. Lu, H. Wang, D. Kong, K. Yan, P.-C. Hsu, G. Zheng, H. Yao, Z. Liang, X. Sun, Y. Cui, "Electrochemical tuning of layered lithium transition metal oxides for improvement of oxygen evolution reaction." Nat. Commun., 5, 4345 (2014).

22. Y. Liu, H. Wang, D. Lin, C. Liu, P.-C. Hsu, W. Liu, W. Chen, Y. Cui, "Electrochemical tuning of olivinetype lithium transition-metal phosphates as efficient water oxidation catalysts." Energy Environ. Sci., 8, 1719-1724 (2015).

23. A. Gupta, W. D. Chemelewski, C. Buddie Mullins, J. B. Goodenough, "High-Rate Oxygen Evolution Reaction on $\mathrm{Al}-$ Doped $\mathrm{LiNiO}_{2}$." Adv. Mater., 27, 6063-6067 (2015).

24. Y. Zhu, W. Zhou, Y. Chen, J. Yu, M. Liu, Z. Shao, "A High-Performance Electrocatalyst for Oxygen Evolution Reaction: $\mathrm{LiCO}_{0.8} \mathrm{Fe}_{0.2} \mathrm{O}_{2}$." Adv. Mater, 27, 7150-7155 (2015).

25. S. Ma, Q. Zhu, L. Chen, W. Wang, D. Chen, "Largescale synthesis of $\mathrm{LiNi}_{0,75} \mathrm{Fe}_{0,25} \mathrm{PO}_{4}$ covalently anchored on graphene nanosheets for remarkable electrochemical water oxidation." J. Mater. Chem. A, 4, 8149-8154 (2016).

26. H. Wang, S. Xu, C. Tsai, Y. Li, C. Liu, J. Zhao, Y. Liu, H. Yuan, F. Abild-Pedersen, F. B. Prinz, "Direct and continuous strain control of catalysts with tunable battery electrode materials." Science, 354, 1031-1036 (2016).

27. J. S. Kim, B. Kim, H. Kim, K. Kang, "Recent Progress on Multimetal Oxide Catalysts for the Oxygen Evolution Reaction.” Adv. Energy Mater., 8, 1702774 (2018)

28. H. Kim, J. Hong, K.-Y. Park, H. Kim, S.-W. Kim, $\mathrm{K}$. Kang, "Aqueous rechargeable $\mathrm{Li}$ and $\mathrm{Na}$ ion batteries." Chem. Rev., 114, 11788-11827 (2014).

29. S. W. Lee, C. Carlton, M. Risch, Y. Surendranath, S. Chen, S. Furutsuki, A. Yamada, D. G. Nocera, Y. Shao-Horn, "The nature of lithium battery materials under oxygen evolution reaction conditions." J. Am. Chem. Soc., 134, 16959-16962 (2012).

30. F. Wang, Y. Han, C. S. Lim, Y. Lu, J. Wang, J. Xu, H. Chen, C. Zhang, M. Hong, X. Liu, "Simultaneous phase and size control of upconversion nanocrystals through lanthanide doping." Nature, 463, 1061 (2010).

31. Y. Zhu, W. Zhou, Y. Chen, J. Yu, X. Xu, C. Su, M. O. Tade', Z. Shao, "Boosting oxygen reduction reaction activity of palladium by stabilizing its unusual oxidation states in perovskite." Chem. Mater., 27, 3048-3054 (2015).

32. P. Strasser, S. Koh, T. Anniyev, J. Greeley, K. More, C. Yu, Z. Liu, S. Kaya, D. Nordlund, H. Ogasawara, "Lattice-strain control of the activity in dealloyed 


\section{특 집 푸 김현아, 강기석}

core-shell fuel cell catalysts." Nat. Chem., 2, 454 (2010).

33. B. Hammer, J. K. Nørskov, "Theoretical surface science and catalysis - calculations and concepts" Advances in catalysis, 45 71-129 (2000).

\section{๑๐ 김현 아}

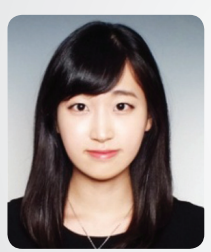

(1) 연세대학교 신소재공학과 학사

( ) 서울대학교 재료공학부 석박통합과정 재학 중

\section{$\circ$ 강 기석}

(1) 서울대학교 재료공학부 학사

- Massachusetts Institute of Technology Materials Science and Engineering 박사

ㅇ KAIST 신소재공학부 교수

()ㅓ울대학교 재료공학부 교수

- Materials Research Society, Board of Directors 